\title{
Vitamin D deficiency is related to thyroid antibodies in autoimmune thyroiditis
}

\author{
ASLI DOGRUK UNAL ${ }^{1}$, OZLEM TARCIN ${ }^{1}$, HULYA PARILDAR ${ }^{2}$, OZLEM CIGERLI ${ }^{2}$, \\ HACER EROGLU ${ }^{3}$, NILGUN GUVENER DEMIRAG ${ }^{1}$
}

'Department of Endocrinology and Metabolism, Baskent University Istanbul Hospital, Istanbul, Turkey

${ }^{2}$ Department of Family Medicine, Baskent University Istanbul Hospital, Istanbul, Turkey

${ }^{3}$ Department of Biochemistry, Baskent University Istanbul Hospital, Istanbul, Turkey

\begin{abstract}
Introduction: It has been known that vitamin D has some immunomodulatory effects and in autoimmune thyroid diseases, vitamin $D$ deficiency was more prevalent. In this study, our aim was to investigate the relationship between thyroid autoantibodies and vitamin $D$.

Material and methods: Group 1 and 2 consisted of 254 and 27 newly diagnosed Hashimoto's thyroiditis (HT) and Graves' disease (GD) cases, respectively; age-matched 124 healthy subjects were enrolled as controls (group 3). All subjects $(n=405)$ were evaluated for $25 O H D$ and thyroid autoantibody [anti-thyroid peroxidase (anti-TPO) and anti-thyroglobulin (anti-tg)] levels.

Results: Group 2 and group 1 patients had lower $25 O H D$ levels than group 3 subjects $14.9 \pm 8.6$ $\mathrm{ng} / \mathrm{ml}, 19.4 \pm 10.1 \mathrm{ng} / \mathrm{ml}$ and $22.5 \pm 15.4 \mathrm{ng} / \mathrm{ml}$, respectively $(p<0.001)$. Serum $250 \mathrm{HD}$ levels inversely correlated with anti-TG $(r=-0.136, p=0.025)$, anti-TPO $(r=-0.176, p=0.003)$ and parathormone $(P T H)(r=-0.240, p<0.001)$. Group 2 patients had higher anti-TG and anti-TPO levels than group 1 and $3(p<0.001)$.

Conclusions: In this study, we found that patients with autoimmune thyroid disease (AITD) present with lower vitamin D levels and GD patients have higher prevalence. Since we found an inverse correlation between vitamin $D$ levels and thyroid antibody levels, we may suggest that vitamin $D$ deficiency is one of the potential factors in pathogenesis of autoimmune thyroid disorders.
\end{abstract}

Key words: vitamin D, thyroid, autoimmunity.

(Centr Eur J Immunol 2014; 39 (4): 493-497)

\section{Introduction}

Vitamin D is a lipid soluble vitamin which affects via vitamin D receptor (VDR). Vitamin D receptor is an intracellular receptor which belongs to the steroid/thyroid nuclear receptor family. This receptor is located in many immune cells, such as neutrophils, macrophages, dendritic cells, T and B cells. In recent years, apart from its primary role in bone and mineral homeostasis, it has been shown that vitamin D has potent immunomodulatory effects both on the innate and adaptive immune system [1-4]. Vitamin D inhibits pro-inflammatory processes by suppressing the over-activity of CD4+, Th1, Th2 and Th17 cells and the production of their related cytokines by the activation of VDR $[1,5]$. Epidemiological studies have shown a relation between vitamin $\mathrm{D}$ deficiency and autoimmune diseases, such as rheumatoid arthritis, systemic sclerosis, systemic lupus erythematosus and autoimmune thyroiditis [6-8].

Autoimmune thyroid diseases (AITDs), including Graves' disease (GD), Hashimoto's thyroiditis (HT) and postpartum thyroiditis, are the most frequently seen autoimmune diseases affecting more than $5 \%$ of population. In recent years, there have been a few studies demonstrating an increase in vitamin D deficiency in HT $[9,10]$.

In this study, our aim was to compare vitamin D levels of newly diagnosed AITDs (GD and HT) and healthy controls and investigate the relation between thyroid autoantibodies and vitamin D deficiency.

\section{Material and methods}

This study was approved by the Baskent University Institutional Review Board and Ethics Committee (Project no. KA13/176) and supported by the Baskent University Research Fund. Informed consent was obtained from all patients and healthy controls.

\section{Study population}

This study population consisted of newly diagnosed AITD adult patients and controls. According to diagno-

Correspondence: Aslı Dogruk Unal, Department of Endocrinology and Metabolism, Baskent University Istanbul Hospital, Mahir Iz str. No: 43, Istanbul, Turkey, tel. 9021647423 04, fax 9021647443 44, e-mail: aslidogruk@yahoo.com 
sis, the study population was separated into three different groups. Hashimoto's thyroiditis patients (diagnosed by elevated antithyroid peroxidase and antithyroglobulin antibodies (TPOAb, TgAb) and basal thyrotrophic hormone (TSH) as well as typical hypoechogenicity of the thyroid in high resolution sonography) were included in group 1 , GD patients [diagnosed by elevated free thyroxine (fT4) and suppressed TSH levels and the presence of diffused goiter and thyroid receptor antibody (TRAb) positivity] in group 2 and controls in group 3. Patients with primary liver and renal failure, diabetes mellitus, metabolic bone disorders, hyperparathyroidism, malignancy, previously known thyroid disorders and on oral contraceptive, anticonvulsant, anti-osteoporotic therapy and other medications that might alter $25(\mathrm{OH}) \mathrm{D}$ or $1,25(\mathrm{OH})_{2} \mathrm{D}$ metabolism and thyroid functions had been excluded from the study.

\section{Laboratory investigation}

For measuring 25(OH)D, TSH, anti-TPO and anti-tg, a blood sample was collected by venipuncture at the fasting state, the serum was separated by centrifugation and then stored at $-70^{\circ} \mathrm{C}$ for a week until analysed.

Vitamin D: Vitamin D status was evaluated by measurement of serum $25(\mathrm{OH})$ D levels with a chemiluminescent immunoassay method (Architect i1000 system); normal range was 8.8-46.3 $\mathrm{ng} / \mathrm{ml}$ (winter); and the intra-assay $\mathrm{CV}$ ranged from 2.6 to $4.0 \%$. Serum $25(\mathrm{OH}) \mathrm{D}$ levels below $20 \mathrm{ng} / \mathrm{ml}$ were considered as deficiency.

Parathormone: Serum PTH levels were measured with an electrochemiluminescent immunoassay method (Architect i2000 system); normal range 15-68 pg/ml; intra-assay CV 3.0-6.5\%. Serum calcium (Ca) levels were measured with an enzymatic colorimetric assay (C8000 system); intra-assay and inter-assay $\mathrm{CV}$ were $0.5-0.6 \%$ and $0.3-0.5 \%$, respectively.

Thyrotrophic hormone, anti-TG, and anti-TPO: TSH, anti-TG, and anti-TPO were also measured with a chemiluminescent immunoassay method (CMIA) (Architect i2000 system, Abbott, USA). The assays have intra-assay precision of $4.3 \%, 5.8 \%$, and $3.2 \%$, respectively. Positive anti-TPO, and anti-tg were defined as a value greater than $5.61 \mathrm{IU} / \mathrm{ml}$ and $4.11 \mathrm{IU} / \mathrm{ml}$, respectively.

\section{Statistical analyses}

Statistical analyses were performed with the Statistical Package for Social Sciences (SPSS for Windows) software (version 17.0, SPSS Inc., Chicago, IL, USA). All parametric variables were given as mean \pm SD or median and interquartile range according to distribution of variables. Distribution of patients was assessed by using visual (histograms, probability plots) and analytical methods (Kolmogorov-Smirnov/Shapiro-Wilk's test). The difference between categorical variables was analyzed with Chisquare test and continuous variables were analyzed with Mann-Whitney $U$ test. As the vitamin D level was not normally distributed even after logarithmic transformation, the data were compared by the non-parametric Mann-Whitney $U$ test. A $p$-value below 0.05 was considered to be statistically significant.

While investigating the associations between non-normally distributed and ordinal variables, the correlation coefficients and their significance were calculated using the Spearman test.

\section{Results}

A total of 405 patients were enrolled in our study. The mean age was $44.6 \pm 13.5$ years and $89.4 \%$ were women in the study population. There was no age difference between 3 groups $(p>0.05)$. A mean vitamin D level of all participants was $20.1 \pm 12 \mathrm{ng} / \mathrm{ml}$. Patients whose serum 25(OH)D levels were below $20 \mathrm{ng} / \mathrm{ml}$ were considered as vitamin D deficient. Sixty five percent (183/281) of the AITDs patients were vitamin $\mathrm{D}$ deficient. When vitamin $\mathrm{D}$ deficient $(n=183)$ and sufficient $(n=98)$ AITDs patients were compared, anti-TG and anti-TPO levels found significantly high in the vitamin D deficient group ( $p=0.02$ and $p=0.003$, respectively, for anti-tg and anti-TPO) (Table 1).

Group 1, group 2 and group 3 consisted of 254, 27 and 124 patients, respectively. The prevalence of vitamin $\mathrm{D}$ insufficiency was $63 \%$ and $85.2 \%$ in group 1 and 2 , respectively. Although the levels of vitamin D were lowest in group 2 (Fig. 1), calcium and PTH levels were similar between groups. Laboratory results of study population are demonstrated in Table 2.

Table 1. Thyroid autoantibody levels according to the vitamin D status

\begin{tabular}{|c|c|c|c|}
\hline & $\begin{array}{l}\text { Vitamin D deficient group } \\
\qquad(n=183)\end{array}$ & $\begin{array}{l}\text { Vitamin D sufficient group } \\
\qquad(n=98)\end{array}$ & $p$ value \\
\hline Vitamin D (ng/ml) & $13.4 \pm 3.6$ & $29.5 \pm 10$ & 0.001 \\
\hline Anti-TG (IU/ml) & $\begin{array}{c}40.4 \\
1.15-1000\end{array}$ & $\begin{array}{c}19.9 \\
1.12-1000\end{array}$ & 0.02 \\
\hline Anti-TPO (IU/ml) & $\begin{array}{c}170.9 \\
0-1000\end{array}$ & $\begin{array}{c}36.8 \\
0.06-1000\end{array}$ & 0.003 \\
\hline
\end{tabular}

Values are expressed as mean $\div S D$ or median with interquartile range

Anti-TG - thyroglobulin antibody, anti-TPO - anti-thyroid peroxidase antibody 
Table 2. Characteristics of the study population

\begin{tabular}{|c|c|c|c|c|}
\hline & Group 1 & Group 2 & Group 3 & $p$ value \\
\hline TSH (mIU/ml) & $\begin{array}{c}2.47 \\
0.16-39.6\end{array}$ & $\begin{array}{c}0.01 \\
0.001-0.67\end{array}$ & $\begin{array}{c}1.75 \\
0.32-7.43\end{array}$ & $<0.001$ \\
\hline Anti-TG (IU/ml) & $\begin{array}{c}29.4 \\
1.12-1000\end{array}$ & $\begin{array}{c}71.1 \\
1.61-1000\end{array}$ & $\begin{array}{c}1.43 \\
0.46-5.71\end{array}$ & $<0.001$ \\
\hline Anti-TPO (IU/ml) & $\begin{array}{l}117.68 \\
0-1000\end{array}$ & $\begin{array}{l}281.36 \\
0-1000\end{array}$ & $\begin{array}{c}0.26 \\
0-4.78\end{array}$ & $<0.001$ \\
\hline PTH (pg/ml) & $\begin{array}{c}46.9 \\
9.14-135.4\end{array}$ & $\begin{array}{c}48.4 \\
25.1-111.2\end{array}$ & $\begin{array}{c}43.1 \\
19.9-134.9\end{array}$ & 0.07 \\
\hline Vitamin D (ng/ml) & $\begin{array}{c}17.05 \\
5.4-80\end{array}$ & $\begin{array}{l}14.9 \\
4-39\end{array}$ & $\begin{array}{c}19.9 \\
9-122.7\end{array}$ & $<0.001$ \\
\hline $\mathrm{Ca}^{2+}(\mathrm{mg} / \mathrm{dl})$ & $\begin{array}{c}9.4 \\
18.4-10.4\end{array}$ & $\begin{array}{c}9.5 \\
8.4-10.4\end{array}$ & $\begin{array}{c}9.5 \\
8.4-10.2\end{array}$ & 0.955 \\
\hline
\end{tabular}

Values are expressed as median with interquartile range.

TSH - thyroid-stimulating hormone, anti-TG - thyroglobulin antibody, anti-TPO - anti-thyroid peroxidase antibody, PTH - parathyroid hormone, Ca - calcium

Multivariate analysis using logistic regression revealed that independent determinants of vitamin $D$ levels were age and $\operatorname{sex}(r=0.17, p=0.004 ; r=-0.15, p=0.01$, respectively). As expected, there was a negative correlation between vitamin D and PTH levels $(r=-0.24, p<0.001)$. When we have investigated the association of thyroid autoantibodies, we found that there was a significant correlation between these autoantibodies and vitamin D and TSH levels (Table 3). Thyroid autoantibodies tended to be higher with lower vitamin D levels and higher TSH levels. Serum PTH levels, however, were not associated with anti-TG and anti-TPO levels.

\section{Discussion}

In this case-control study, patients with autoimmune thyroid diseases (HT and GD) had lower 25(OH)D levels than healthy subjects and vitamin D levels were the lowest in GD patients. Since we have known from our previous and other Turkish studies that vitamin D deficiency has been a prevalent health problem in our country, we adopted a cutoff level of vitamin D level as $20 \mathrm{ng} / \mathrm{ml}$ [21-23]. According to this cutoff value, $60.7 \%$ of our study population had vitamin $\mathrm{D}$ deficiency.

It has been known that vitamin D deficiency is not correlated with severity of hyperthyroidism [24, 25], and antithyroid drugs have immunosuppressive effects. In addition, thyroid hormones relatively affect renal activity of $1 \alpha$-hydroxlase and plasma $1,25(\mathrm{OH})_{2} \mathrm{D}$ levels $[26,27]$. For these reasons, only newly diagnosed AITDs patients were included and we measured 25(OH)D level instead of $1,25(\mathrm{OH})_{2} \mathrm{D}$ in our study.

Autoimmune thyroid diseases are relatively common organ-specific autoimmune disorders that cause diseases ranging in severity from hypothyroidism (HT) to hyperthyroidism (GD) [28]. The effects of various environmental
Table 3. Correlation between thyroid autoantibodies and vitamin D and TSH levels

\begin{tabular}{lcc}
\hline & Vitamin D & TSH \\
\hline Anti-TG & & \\
$r$ & -0.13 & 0.144 \\
$p$ & 0.025 & 0.018 \\
\hline Anti-TPO & \\
$r$ & & 0.21 \\
$p$ & -0.17 & 0.001 \\
\hline TSH - thyroid-stimulating hormone, anti-TG - thyroglobulin antibody, anti- \\
TPO- anti-thyroid peroxidase antibody
\end{tabular}

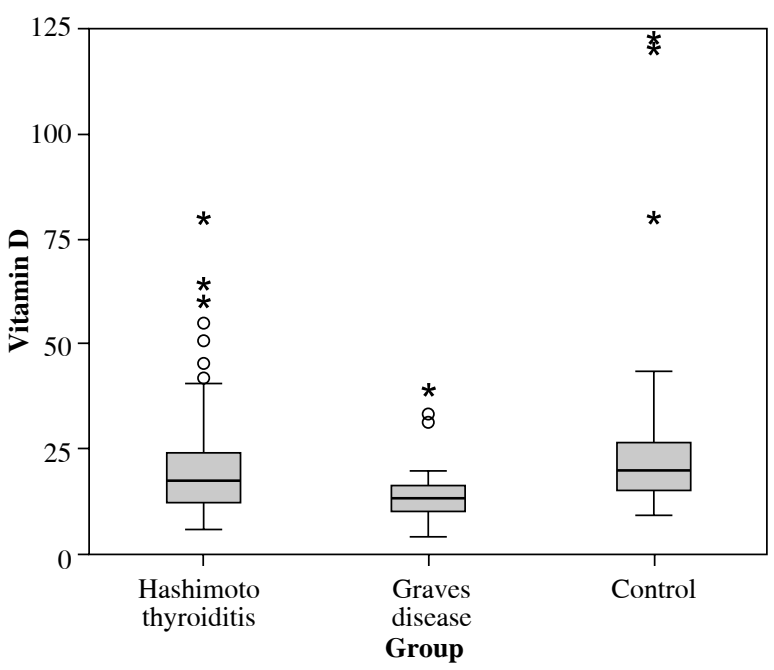

Fig. 1. Vitamin D levels in each group

factors and the intrinsic genetic predisposition of an individual may lead to a loss of self-tolerance and contribute to the initiation of AITDs. In pathological conditions like thyroiditis, infiltrating lymphocytes, cell surface expression of MHCII, Fas-mediated apoptosis and cytokines re- 
leased from both immune cells and thyrocytes contribute to amplification and progression of AITD [29-34]. According to this theory, as a result of defective suppressor $\mathrm{T}$ cells, Th (CD4) cells are able to activate and cooperate with B lymphocytes. B lymphocytes activated by T lymphocytes produce antibodies that react with thyroid antigens. Studies on HT and GD patients had reported low vitamin D levels $[9,10,35,36]$. Consistent with the literature, we found a lower vitamin D level in patients with autoimmune thyroiditis (GD group and HT group) than in controls. In addition, this is the first study that found a statistically significant negative correlation between serum 25(OH)D and anti-TPO, anti-TG levels in both HT and GD patients.

\section{Conclusions}

Our findings indicate that patients with AITD present with lower vitamin D levels and GD patients have higher prevalence. Since we found an inverse correlation between vitamin D levels and thyroid antibody levels, we might speculate that there might exist a casual relationship. However, these findings do not clarify whether treatment with vitamin D has any beneficial effect on progression or remission of AITD. So, further studies specifically designed to evaluate the beneficial effect of vitamin D supplementation on AITD are needed.

\section{The authors declare no conflict of interest.}

\section{References}

1. Arnson Y, Amital H, Shoenfeld Y (2007): Vitamin D and autoimmunity: new aetiological and therapeutic considerations. Ann Rheum Dis 66: 1137-1142.

2. Baeke F, Takiishi T, Korf H, et al. (2010): Vitamin D: modulator of the immune system. Curr Opin Pharmacol 10: 482496.

3. Deluca HF, Cantorna MT (2001): Vitamin D: its role and uses in immunology. FASEB J 15: 2579-2585.

4. Cantorna MT, Mahon BD (2004): Mounting evidence for vitamin $\mathrm{D}$ as an environmental factor affecting autoimmune disease prevalence. Exp Biol Med 229: 1136-1142.

5. Tang J, Zhou R, Luger D, et al. (2009): Calcitriol suppresses antiretinal autoimmunity through inhibitory effects on the Th17 effector response. J Immunol 182: 4624-4632.

6. Cutolo M, Otsa K, Uprus M, et al. (2007): Vitamin D in rheumatoid arthritis. Autoimmun Rev 7: 59-64.

7. Doria A, Arienti S, Rampudda M, et al. (2008): Preventive strategies in systemic lupus erythematosus. Autoimmun Rev 7: 192-197.

8. Kamen DL, Cooper GS, Bouali H, et al. (2006): Vitamin D deficiency in systemic lupus erythematosus. Autoimmun Rev 5: 114-117.

9. Tamer G, Arik S, Tamer I, Coksert D (2011): Relative vitamin D insufficiency in Hashimoto's thyroiditis. Thyroid 21: 891-896.

10. Bozkurt NC, Karbek B, Ucan B, et al. (2013): The association between severity of vitamin D deficiency and Hashimoto's thyroiditis. Endocr Pract 19: 479-484.
11. Cantorna MT, Zhu Y, Froicu M, Wittke A (2004): Vitamin D status, 1,25-dihydroxyvitamin D3, and the immune system. Am J Clin Nutr 80: 1717S-1720S.

12. Li HS, Verginis P, Carayanniotis G (2006): Maturation of dendritic cells by necrotic thyrocytes facilitates induction of experimental autoimmune thyroiditis. Clin Exp Immunol 144: 467-474.

13. Antico A, Tampoia M, Tozzoli R, Bizzaro N (2012): Can supplementation with vitamin $\mathrm{D}$ reduce the risk or modify the course of autoimmune diseases? A systematic review of the literature. Autoimmun Rev 12: 127-136.

14. Ikeda U, Wakita D, Ohkuri T, et al. (2010): 1alpha,25-Dihydroxyvitamin D3 and all-trans retinoic acid synergistically inhibit the differentiation and expansion of Th17 cells. Immunol Lett 134: 7-16.

15. Taher YA, van Esch BC, Hofman GA, et al. (2008): 1alpha,25-dihydroxyvitamin D3 potentiates the beneficial effects of allergen immunotherapy in a mouse model of allergic asthma: role for IL-10 and TGF-beta. J Immunol 180: 5211-5221.

16. Hewison M, Freeman L, Hughes SV, et al. (2003): Differential regulation of vitamin $\mathrm{D}$ receptor and its ligand in human monocyte-derived dendritic cells. J Immunol 170: 5382-5390.

17. Piemonti L, Monti P, Sironi M, et al. (2000): Vitamin D3 affects differentiation, maturation, and function of human monocyte-derived dendritic cells. J Immunol 164: 4443-4451.

18. Széles L, Keresztes G, Töröcsik D, et al. (2009): 1,25-dihydroxyvitamin D3 is an autonomous regulator of the transcriptional changes leading to a tolerogenic dendritic cell phenotype. J Immunol 182: 2074-2083.

19. Correale J, Ysrraelit MC, Gaitán MI (2011): Vitamin D-mediated immune regulation in multiple sclerosis. J Neurol Sci 311: 23-31.

20. Kivity S, Agmon-Levin N, Zisappl M, et al. (2011): Vitamin $\mathrm{D}$ and autoimmune thyroid diseases. Cell Mol Immunol 8: 243-247.

21. Cigerli O, Parildar H, Unal AD, et al. (2013): Vitamin D deficiency is a problem for adult out-patients? A university hospital sample in Istanbul, Turkey. Public Health Nutr 16: 1306-1313.

22. Erkal MZ, Wilde J, Bilgin Y, et al. (2006): High prevalence of vitamin D deficiency, secondary hyperparathyroidism and generalized bone pain in Turkish immigrants in Germany: identification of risk factors. Osteoporos Int 17: 1133-1140.

23. Ralston SH, Binkley N, Boonen S, et al. (2011): Randomized trial of alendronate plus vitamin D3 versus standard care in osteoporotic postmenopausal women with vitamin D insufficiency. Calcif Tissue Int 88: 485-494.

24. Fournier C, Gepner P, Sadouk M, Charreire J (1990): In vivo beneficial effects of cyclosporin A and 1,25-dihydroxyvitamin D3 on the induction of experimental autoimmune thyroiditis. Clin Immunol Immunopathol 54: 53-63.

25. Misharin A, Hewison M, Chen CR, et al. (2009): Vitamin D deficiency modulates Graves' hyperthyroidism induced in BALB/c mice by thyrotropin receptor immunization. Endocrinology 150: 1051-1060.

26. Kozai M, Yamamoto H, Ishiguro M, et al. (2013): Thyroid hormones decrease plasma 1alpha,25-dihydroxyvitamin D levels through transcriptional repression of the renal 25-hydroxyvitamin D3 1alpha-hydroxylase gene (CYP27B1). Endocrinology 154: 609-622.

27. Pantazi H, Papapetrou PD (2000): Changes in parameters of bone and mineral metabolism during therapy for hyperthyroidism. J Clin Endocrinol Metab 85: 1099-1106. 
28. Hollowell JG, Staehling NW, Flanders WD, et al. (2002): Serum TSH, T(4), and thyroid antibodies in the United States population (1988 to 1994): National Health and Nutrition Examination Survey (NHANES III). J Clin Endocrinol Metab 87: 489-499.

29. Ng HP, Banga JP, Kung AW (2004): Development of a murine model of autoimmune thyroiditis induced with homologous mouse thyroid peroxidase. Endocrinology 145: 809-816.

30. McLachlan SM, Nagayama Y, Rapoport B (2005): Insight into Graves' hyperthyroidism from animal models. Endocr Rev 26: 800-832.

31. Many MC, Maniratunga S, Varis I, et al. (1995): Two-step development of Hashimoto-like thyroiditis in genetically autoimmune prone non-obese diabetic mice: effects of iodine-induced cell necrosis. J Endocrinol 147: 311-320.

32. Caturegli P, Hejazi M, Suzuki K, et al. (2000): Hypothyroidism in transgenic mice expressing IFN-gamma in the thyroid. Proc Natl Acad Sci U S A 97: 1719-1724.

33. Kimura H, Kimura M, Tzou SC, et al. (2005): Expression of class II major histocompatibility complex molecules on thyrocytes does not cause spontaneous thyroiditis but mildly increases its severity after immunization. Endocrinology 146: 1154-1162.

34. Nagayama Y (2005): Animal models of Graves' hyperthyroidism. Endocr J 52: 385-394.

35. Yasuda T, Okamoto Y, Hamada N, et al. (2012): Serum vitamin $\mathrm{D}$ levels are decreased and associated with thyroid volume in female patients with newly onset Graves' disease. Endocrine 42: 739-741.

36. Yasuda T, Okamoto Y, Hamada N, et al. (2013): Serum vitamin D levels are decreased in patients without remission of Graves' disease. Endocrine 43: 230-232. 